REVISTA de

PEDAGOGIE

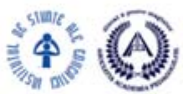

JOURNAL of

PEDAGOGY

http://revped.ise.ro

Print ISSN 0034-8678; Online ISSN: 2559 - 639X

\title{
OPTIONAL SUBJECTS IN THE ROMANIAN SCHOOL: PARENTS' OPINIONS
}

DISCIPLINELE OPȚIONALE ÎN ȘCOALA ROMÂNEASCĂ: OPINII ALE PĂRINȚILOR

\section{Luminița CATANĂ, Mădălina ANGELUȘIU}

Journal of Pedagogy, 2018 (2), 189 - 209

https://doi.org/10.26755/RevPed/2018.2/189

The online version of this article can be found at: http://revped.ise.ro/category/2018-en/

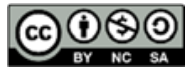

This work is licensed under the Creative Commons Attribution-NonCommercial-ShareAlike 4.0 International License.

To view a copy of this license, visit http://creativecommons.org/licenses/by-nc-sa/4.0/ or send a letter to Creative Commons, PO Box 1866, Mountain View, CA 94042, USA

Published by:

\section{INSTITUTUL DE ȘTIINTTE ALE EDUCAȚIEI}

http://www.ise.ro/

Further information about Revista de Pedagogie - Journal of Pedagogy can be found at:

Editorial Policy: http://revped.ise.ro/editorial-policy/

Author Guidelines: http://revped.ise.ro/the-writer-guide-2/ 


\title{
DISCIPLINELE OP IONALE ÎN ŞCOALA ROMÂNEASCĂ: OPINII ALE PĂRIN ILOR
}

\author{
Institutul de Ştiin e ale Educa iei \\ Bucureşti, România \\ luminita.catana@ise.ro \\ madalina.angelusiu@ise.ro
}

Mădălina Angeluşiu**

\section{Rezumat}

Sunt mai mult de două decenii de când şcolile din România se bucură de autonomie privind oferta curriculară. Modul în care sunt propuse şi selectate astăzi disciplinele op ionale de către beneficiari, precum şi modalitatea de desfăşurare la clasă, reflectă experien ele particulare ale şcolilor acumulate în aceşti ani, privind elaborarea şi avizarea disciplinelor op ionale. Există mai multe studii care eviden iază aprecierile elevilor şi ale profesorilor cu privire la disciplinele op ionale; articolul de fa ă îşi propune însă să sublinieze percep iile părin ilor care au copii în gimnaziu, despre calitatea op ionalelor şi despre procesul de elaborare şi avizare a acestora. Opiniile părin ilor devin importante din perspectiva implicării lor în educa ia propriilor copii, mai ales pe durata studiilor gimnaziale.

Cuvinte-cheie: Autonomie şcolară, curriculum la decizia şcolii, discipline op ionale, percep ii ale părin ilor.

\section{Abstract}

There are more than two decades since the Romanian schools have autonomy on optional school subjects. The way these optional subjects are proposed today reflects the schools' experience, accumulated during this period, regarding their elaboration and approval. There are several studies highlighting how these optional subjects are evaluated by students and teachers; this paper aims to complete the picture and to emphasize the perceptions of the parents having

\footnotetext{
* Cercetător ştiin ific dr., Institutul de Ştiin e ale Educa iei, Bucureşti, România.

** Cercetător ştiin ific, Institutul de Ştiin e ale Educa iei, Bucureşti, România.
} 
children in gymnasium, regarding the optional school subjects, as components of the curriculum at the school's decision. The parents' opinions become important from the perspective of their involvement in the formal education of their children.

Keywords: Curriculum at the school's decision, optional school subjects, parents' perceptions, school autonomy.

\section{Introducere}

Curriculumul la decizia şcolii (notat prescurtat CDŞ) poate fi definit ca ,un ansamblu de procese educative şi de experien e de învă are oferite de şcoală, articulate în cadrul unor discipline diferite de cele din trunchiul comun" (Mândru , 2009, p. 5).

Conform Legii Educa iei Na ionale nr. 1/2011, art. 65(5), ,,curriculumul la decizia şcolii se constituie atât din pachete disciplinare op ionale ofertate la nivel na ional, regional şi local, cât şi din pachete disciplinare op ionale ofertate la nivelul unită ii de învă ământ. Consiliul de administra ie al unită ii de învă ământ, în urma consultării elevilor, părin ilor şi pe baza resurselor disponibile, stabileşte curriculumul la decizia şcolii”.

Ulterior, a fost elaborată Metodologia privind elaborarea şi aprobarea curriculumului şcolar - planuri-cadru de învă ământ şi programe şcolare (anexă la Ordinul ministrului educa iei na ionale nr. 3593/18.06.2014), în care se precizează că atât curriculumul la decizia şcolii (CDŞ) şi curriculumul în dezvoltare locală (CDL), ,reprezintă oferta educa ională propusă de şcoală, în concordan ă cu nevoile şi interesele de învă are ale elevilor, cu specificul şcolii şi cu nevoile comunită ii locale/partenerilor economici" (art. 2. lit. g.). În aceeaşi metodologie sunt men ionate etapele parcurse în elaborarea/aprobarea unui CDŞ (la art.17).

Bugetul de timp alocat disciplinelor op ionale, după cum rezultă din actualele planuri-cadru de învă ământ, reprezintă doar o mică parte din numărul total de ore alocate unei clase, respectiv 1-3 ore din totalul de 26-28 ore în clasa a V-a, 1-3 ore din 26-30 ore în clasa a VI-a, 1-3 ore din 31-33 ore în clasa a VII-a şi 1-4 ore din 31-34 ore în clasa a VIII-a. 
Pentru o institu ie şcolară, posibilitatea de a propune discipline op ionale personalizate reprezintă o şansă de a adapta curriculumul la particularită ile şi aspira iile elevilor săi, dar înseamnă şi asumarea unor decizii curriculare luate în mod democratic, prin implicarea persoanelor direct interesate: comunitate, părin i, elevi şi profesori. Puterea şcolii derivă din libertatea oferită de planurile-cadru de a decide asupra unui segment din curriculumul şcolar şi de a genera astfel diverse trasee personalizate de învă are. Deşi filosofia care stă în spatele op ionalelor este bine conturată, dezvoltarea acestei zone curriculare a înregistrat diverse fluctua ii de-a lungul timpului, pe măsură ce şcolile au acumulat experien e pozitive sau negative. Ca urmare a aprecierilor privind aceste discipline şi a rezultatelor ob inute de elevii participan i la aceste cursuri, oferta s-a modificat în timp, astfel că unele discipline şi-au schimbat structura sau modalitatea de abordare a cunoaşterii, în timp ce la alte discipline s-a renun at complet, fiind înlocuite cu altele.

La nivel declarativ, după 1998, anul oficializării op ionalelor, acestea reprezentau de fapt o inova ie de vârf şi o provocare pentru şcoli. Toate şcolile erau invitate să iasă din modul lor obişnuit de func ionare şi să devină mai dinamice şi mai responsabile în privin a ofertei de educa ie, iar profesorii mai creativi. La început a fost constatată o oarecare iner ie a şcolilor, şi tendin a de a limita numărul de op ionale sau, uneori, de a le clona, indiferent de anul de studiu, fără eviden a unui progres la nivel de competen e de la un an la altul (de exemplu, în cazul disciplinelor care urmăreau utilizarea calculatorului). De asemenea, a existat şi tenta ia unor şcoli de a prelua în mod automat op ionalele aprobate la nivel central, tenta ie care se manifestă şi în prezent.

La nivel managerial, situa ia respectivă putea fi explicată prin dorin a conducerii şcolii de a avea stabilitate, inclusiv la nivelul ofertei disciplinare, în plin proces de reforme în învă ământ, dar şi prin teama că redirec ionarea unei păr i din timpul şi efortul profesorilor pentru elaborarea materialelor necesare aprobării acestor discipline ar fi dus la supraîncărcarea acestora, cu efecte nedorite asupra calită ii altor activită i didactice; în general, în condi iile unei concuren e reale între şcoli, ,stabilitatea institu ională garantează maximum de randament la un moment dat, iar orice schimbare duce automat la scăderea eficien ei, cel pu in până se formează noi obişnuin e" (Brickell, 1974, p. 502). S-a remarcat faptul că, într-un sistem relativ stabil, 
cum este şi cazul unei şcoli, ini iativele personale şi inova iile curriculare au fost şi încă sunt mai greu acceptate, deoarece ,,cea mai mare parte a energiei disponibile se cheltuieşte pentru executarea unor opera ii curente şi pentru men inerea rela iilor din interiorul sistemului. Frac iunea de energie care rămâne pentru problemele de diagnosticare, de planificare, de inovare, de schimbare şi de dezvoltare, este astfel - cel mai adesea - foarte redusă" (Miles, 1964, p. 443).

\section{Locul disciplinelor op ionale în oferta curriculară a şcolii}

Învă ământul obligatoriu este construit în România, ca de altfel în toate ările europene, pe baza sistemului european de competen e-cheie, sistem care ar trebui să asigure un fundament solid pentru învă area pe tot parcursul vie ii. Deşi competen ele-cheie con in elemente transdisciplinare, realizarea de pun i între diverse teorii disciplinare sau între elementele teoretice dintr-o disciplină şi aplicarea acestora în rezolvarea problemelor practice se realizează încă timid la nivelul planificării şi al aplicării la clasă, din două cauze majore:

a) dificultatea identificării şi dezvoltării temelor cu poten ial interdisciplinar;

b) formarea ini ială a profesorilor, care este monodisciplinară.

De fapt, cele două aspecte sunt interconectate, iar principalul factor limitativ este însăşi limitarea expertizei profesorilor. Deoarece disciplinele obligatorii sunt, cu unele excep ii, discipline fundamentale ale cunoaşterii umane (aşa cum este cazul matematicii, fizicii, chimiei, biologiei etc.), efortul profesorilor a fost îndreptat, în principal, către rafinarea ofertei de activită i de învă are, prin includerea în orele de trunchi comun a unor activită i transdisciplinare sau a unor aplica ii practice, cotidiene, înscrise într-o tematică dată. Există însă şi discipline care, prin natura lor, propun abordări integrate, multidisciplinare mai complexe. De exemplu, programa Matematica şi explorarea mediului, pentru clasa pregătitoare, clasa I şi a II-a, acumulează competen e din mai multe domenii; Geografia este un alt exemplu de disciplină care este construită ca o sinteză între ştiin ele naturii şi ştiin e sociale şi de aceea oferă o viziune integrată asupra realită ii; Ştiin ele naturii, în clasele a III-a şi a IV-a, constituie o disciplină obligatorie care integrează 
competen e specifice fizicii, botanicii, zoologiei. Acestea discipline men ionate dispun de ,,abordări supradisciplinare şi interdisciplinare care îmbină metode de investiga ie din diverse discipline ale naturii” (Catană \& Mândru , 2011, p. 94).

Cu toate aceste exemple, rămâne încă deschisă discu ia privind modalită ile concrete de a conecta cunoaşterea din diverse domenii într-o ofertă consistentă de situa ii de învă are, care să favorizeze anumite transferuri de cunoştin e şi metode, în vederea rezolvării de probleme mai complexe. Abordările interdisciplinare sau cele integrate ,nu conduc la renun area la disciplinele tradi ionale, ci la modalită i mai practice de organizare curriculară" (Potolea, 2012, p. 27). Ca modalită i de abordare a interdisciplinarită ii, pedagogii men ionează cel mai adesea metoda proiectelor şcolare sau aplicarea unor cunoştin e în situa ii cotidiene. Situa ia este similară cu cea înregistrată în alte ări, în care se caută încă modalită i moderne de organizare curriculară.

Revizuirile recente ale programelor şcolare din trunchiul comun constrâng şcolile la revizuirea curriculumului la decizia şcolii. Inova iile curriculare sunt necesare şi sunt impuse de nevoia de a realiza un echilibru între disciplinele obligatorii şi cele op ionale, pe baza principiului îmbinării abordărilor disciplinare cu cele de tip multi-, pluri-, inter-şi transdisciplinare. Acest principiu de elaborare a ofertei educa ionale a dus la decizia de reducere a numărului de ore destinate trunchiului comun, comparativ cu planurile cadru anterioare şi la alocarea unor ore suplimentare din programul săptămânal al elevilor, pentru disciplinele op ionale.

Pentru unii specialişti în educa ie, abordarea integrată rămâne încă o intă de osmoză curriculară, deoarece ,,presupune interdisciplinaritate nu numai la nivelul con inuturilor, ci şi al întregii experien e de predare - învă are" ( ăranu, 2003, p. 94.); al i specialişti afirmă existen a mai multor niveluri de integrare curriculară: multidisciplinar, pluridisciplinar, interdisciplinar sau transdisciplinar (Potolea, 2012, p. 168). O clasificare frecvent utilizată a op ionalelor, inclusiv la nivelul documentelor curriculare oficiale, a fost: op ional la nivel de disciplină, op ional la nivel de arie, respectiv, op ional între arii curriculare (Mândru , pp. 14-15). 
Construc ia unui CDŞ poate fi realizată pornind de la identificarea unor conexiuni interdisciplinare sau printr-un parcurs invers, pornind de la experien ele extraşcolare ale elevului, caz în care disciplina va fi centrată pe explorarea unor situa ii problematice din via a de zi cu zi, pe realizarea unor proiecte personale sau pe realizarea unor produse. Psihologul american Howard E. Gardner este de părere că aceste discipline op ionale pot fi astfel construite încât să servească ,,drept puncte de plecare pentru în elegerea unor întrebări mai serioase despre lume" (Gardner, 2005, p. 169). Indiferent de modul de elaborare, de structură, de deprinderile sau de atitudinile pe care le dezvoltă, disciplinele op ionale ar trebui să fie liantul curricular între disciplinele obligatorii, prin intermediul lor fiind sus inută structura complexă a sistemului european de competen e-cheie. Gardner a subliniat limitele educa iei disciplinare, arătând că fiecare disciplină propune doar o perspectivă pentru o temă dată: ,„educa ia nu poate pune la dispozi ia fiecărui elev câte o pereche de ochelari pentru fiecare caz [adică pentru fiecare disciplină]; chiar am putea spune că suntem sorti i eşecului dacă încercăm să transformăm fiecare elev într-un istoric, biolog sau un compozitor de muzică clasică. [...] educa ia are succes dacă îi face pe elevi să vadă cum apare lumea în ochii unor indivizi care poartă ochelari foarte diferi i” (Gardner, 2005, p. 169).

Modalitatea de construire a op ionalelor pornind de la experien ele cotidiene ale elevilor este preferată, de exemplu, în Marea Britanie. În această ară sunt propuse pu ine discipline obligatorii şi există chiar o sugestie explicită de a completa oferta şcolii cu discipline care acoperă anumite nevoi cotidiene ale elevului sau ale comunită ii din care acesta face parte, precum: educa ie personală şi socială; educa ie civică; o limbă străină (la alegere); educa ie sexuală; educa ie şi orientare profesională, după clasa a IX-a (Department for Education, 2011).

\section{Finalită ile disciplinelor op ionale din gimnaziu}

În România, la finalul ciclului gimnazial, un absolvent trebuie să de ină competen e-cheie la un nivel func ional (Institutul de Ştiin e ale Educa iei, 2016, p. 7). Acest nivel descrie o dezvoltare armonioasă a elevului în func ie de cinci dimensiuni ale dezvoltării umane, definite în document prin: dezvoltare cognitivă şi socioemo ională, internalizarea normelor şi valorilor, autocunoaştere 
şi reflec ie, autonomie în învă are şi creativitate. Aceste perspective pot constitui, de fapt, cinci direc ii de elaborare a unor op ionale care pot să completeze aspecte insuficient formate în cadrul disciplinelor obligatorii. De exemplu, la categoria „,creativitate” poate fi înscris un curs de general de tehnici de gândire şi expresie creativă sau un curs care dezvoltă creativitatea într-un singur domeniu (de exemplu, un curs de crea ie literară, un curs de matematică bazat pe metode euristice, un curs de TIC cu metode colaborative pentru crea ii muzicale etc.).

Este cazul să amintim că, în prezent, sunt în uz câteva discipline op ionale interdisciplinare, aprobate la nivel central, care pot fi preluate la nivel de şcoală (câteva exemple: Joc şi mişcare pentru clasele I şi a II-a; Matematica şi ştiin ele în societatea cunoaşterii; Pregăti $i$ pentru via ă! pentru învă ământul primar; Educa ie pentru sănătate; Lectură şi abilită $i$ de via $\breve{a}$, pentru învă ământul primar şi gimnazial; Ştiin $e$, destinate profilului umanist, filologie sau unor specialită i din profilul voca ional). Cunoaşterea acestor programe este utilă, nu numai pentru că ele sunt exemple de op ionale deja aprobate, dar şi pentru că au la bază construc ii curriculare coerente, care pot fi luate ca exemple de către profesori.

O poveste mai veche privind modul în care apreciază un profesor utilitatea competen elor, poate fi şi astăzi un exemplu de reflec ie pentru profesorul modern (Cocişiu, 2012). Povestea ne îndeamnă să ne imaginăm un inspector care vede în curtea unei şcoli o moară de apă care zdrobeşte grăun e, un teasc pentru ulei şi alte asemenea obiecte lucrate de un elev pasionat de tehnologie, toate acestea func ionând. Cu toate aceste realizări personale care dezvăluie calită ile elevului respectiv pentru aplicarea în practică a fizicii şi a tehnologiei, elevul respectiv are cea mai mică notă la fizică. Elevul utilizează cu succes principiile fizicii şi cunoştin e tehnologice, dar într-un mod intuitiv sau pe baza unor analogii cu ceea ce a observat anterior la alte maşinării, deşi nu cunoaşte elementele teoretice predate la clasă. Profesorul de fizică este întrebat cum îşi explică notele modeste ale acestui elev la fizică. Răspunsul profesorului în privin a elevului genial a fost că ,nu-i nici o mirare, deoarece, se ştie, elevul inventator răspunde slab la lec ie. Talentul său nu priveşte specialitatea mea [fizica] atât de direct, cât îl priveşte pe profesorul de lucru manual" (după Cocişiu, T., p. 13). Povestea este despre cum sunt şi astăzi privite disciplinele şcolare, inclusiv cele fundamentale, în 
legătură cu finalită ile propuse, respectiv izolat şi fără a se avea în vedere utilitatea lor practică. Astfel, competen ele asociate unei discipline au o arie de cuprindere mai vastă, iar aplicarea achizi iilor în via a de zi cu zi reprezintă, de fapt, nivelul cel mai ridicat de manifestare a unei competen e disciplinare. Această capacitate de a utiliza ceea ce cunoaştem, când avem nevoie, reprezintă în fapt semnifica ia competen elor, dincolo de defini iile din documentele oficiale.

Astfel de activită i practice s-ar încadra foarte bine în orice programă de trunchi comun sau disciplină op ională, mai ales în disciplinele din aria Matematică şi Ştiin e ale naturii sau la Tehnologii, la gimnaziu, unde este accentuată viziunea de abordare intuitiv-creativă a cunoaşterii.

\section{Procesul de propunere, selec ie şi aprobare a disciplinelor op ionale}

Op ionalele reprezintă, pe de-o parte, o şansă pentru elevi de a propune şi alege anumite discipline care corespund mai bine intereselor lor de cunoaştere şi, pe de altă parte, oferă profesorului oportunitatea de a organiza mai bine învă area elevilor, de a preda altfel, de a aborda competen e şi con inuturi ce nu sunt vizate de disciplinele de trunchi comun sau de a evalua elevii folosind şi alte metode decât cele clasice.

Acest proces de propunere a op ionalelor, care ar trebui să îi implice activ pe elevi, este limitat la experien ele lor anterioare şi acesta poate fi principalul motiv pentru care profesorii şcolii sunt, de regulă, cei care propun listele cu discipline op ionale.

Efectele benefice sau, dimpotrivă, efectele nedorite care apar datorită includerii op ionalelor în orarul elevilor din învă ământul obligatoriu au fost şi rămân subiecte de discu ie între părin i, profesori şi elevi. Recent, într-un sondaj de opinie (Balica \& Fartuşnic, 2018) au fost eviden iate percep iile generale ale profesorilor care predau în şcoli şi licee, cu privire la disciplinele op ionale derulate în şcolile de unde provin. 
Referitor la propunerea acestor discipline, profesorii sunt de părere că există limite impuse de pregătirea lor ini ială şi continuă, dar şi limite datorate timpului de care dispun pentru realizarea documenta iei, programei şi materialelor necesare, deşi temele respective reflectă în mare măsură preocupări şi pasiuni dezvoltate în timp. Există op ionale dorite în şcoli, dar pentru care profesorii au nevoie de cursuri de perfec ionare, mai ales pentru anumite domenii noi, de vârf (alt aspect delicat fiind costul unei astfel de formări, care poate fi greu de suportat de către un profesor).

Procesul de avizare la nivelul unor structuri şcolare (consiliu profesoral, inspectorat şcolar, consiliu de administra ie) este, în opinia unor profesori, anevoios şi implică mult efort din partea unui profesor. Unii profesori nu au cunoştin ele necesare pentru a elabora documentele necesare unui CDŞ, deşi au experien ă didactică în domeniul respectiv, iar aceasta poate fi o explica ie rezonabilă pentru sărăcirea ofertei curriculare. Ca urmare a acestei situa ii, elevii şi părin ii au, în unele şcoli, mai pu ine posibilită i de a alege un curs op ional. Mai mult decât atât, aceste discipline op ionale se aplică unei întregi clase de elevi, nu se organizează pe grupe de interese, aşa că deseori şcoala impune de fapt elevilor aceste op ionale. Uneori acestea sunt văzute şi ca o modalitate de a completa normele didactice ale profesorilor.

Unii profesori aduc în discu ie slaba dotare materială a şcolilor, lipsa aparaturii de laborator făcând anevoioasă sau chiar imposibilă desfăşurarea activită ilor din cadrul unor discipline op ionale cu un caracter aplicativ mai amplu. Experimentele şi lucrările practice sunt realizate numai în şcolile care dispun de laboratoare şi de materialele necesare şi numai în măsura în care aceste activită i se pot încadra în timpul pe care îl au profesorii la dispozi ie. De aici rezultă şi tendin a unor profesori de a exclude experimentele şi lucrările de laborator, care ar contribui la formarea deprinderilor practice ale elevilor, atât din disciplinele obligatorii, cât şi din cele op ionale.

\section{Metodologia cercetării}

Scopul acestei cercetări a fost de a pune în eviden ă percep iile părin ilor, ca beneficiari secundari ai educa iei obligatorii, cu privire la disciplinele op ionale dintr-o şcoală. 
Primul obiectiv a fost clarificarea motivelor pentru care sunt propuse aceste op ionale. Teoretic, un op ional ar trebui prezentat elevilor şi părin ilor în cadrul unei şedin e comune, în care să fie subliniată importan a sa pentru formarea armonioasă a personalită ii elevilor şi structura disciplinei respective.

Al doilea obiectiv a vizat colectarea şi interpretarea opiniilor părin ilor privind selectarea disciplinelor op ionale din şcoală, respectiv identificarea celor mai importan i factori care intervin în aceste alegeri. O ipoteză legată de acest obiectiv a fost că, de obicei, acestea sunt propuse pe baza unor liste elaborate de către profesori şi selectate de părin i în grabă, în cadrul unor şedin e care au loc în fiecare an, votul părin ilor fiind determinant.

Cel de-al treilea obiectiv a vizat identificarea şi analizarea aprecierilor părin ilor privind utilitatea acestor op ionale, exprimate pe baza unor experien e particulare.

Metoda utilizată pentru a colecta opiniile părin ilor a fost ancheta pe bază de chestionar. Cercetarea a fost realizată în perioada martie-mai 2018, pe un eşantion de 160 de persoane având copii în învă ământul gimnazial (clasele V-VIII). Chestionarul administrat a inclus 10 itemi, dintre care 6 itemi de tip obiectiv, un item semiobiectiv şi 3 itemi subiectivi. Toate persoanele din eşantion au oferit răspunsuri valide pentru fiecare item.

Evaluarea răspunsurilor s-a făcut pe baza unei scale Likert în 5 trepte. Tendin ele centrale ale opiniilor părin ilor au fost determinate prin calcularea mediilor valorilor numerice alocate răspunsurilor, iar ca indicatori sintetici ai varia iei răspunsurilor au fost utiliza i abaterea standard (abaterea medie pătratică), respectiv coeficientul de varia ie, cu ajutorul cărora s-a stabilit gradul de omogenitate al răspunsurilor, respectiv a fost verificat dacă tendin a centrală rezultată din calculul mediei este sau nu reprezentativă pentru eşantion. Măsurarea gradului de legătură dintre diferite variabile s-a făcut cu ajutorul coeficientului de corela ie a lui Pearson, iar interdependen a dintre variabilele respective a fost descrisă matematic printr-o ecua ie de regresie liniară.

Limitele acestei cercetări sunt date, în principal, de constituirea eşantionului de părin i care au răspuns la chestionar. Chestionarul a fost aplicat într-un număr relativ restrâns de şcoli din mediul urban şi, de aceea, rezultatele 
ob inute pot fi extrapolate numai pentru acest mediu, neavând certitudinea că ele pot fi regăsite şi în mediul rural. Deşi cei mai mul i dintre responden i nu sunt specialişti în elaborarea curriculumului, aprecierile lor pot constitui un ajutor valoros pentru ajustarea criteriilor de calitate referitoare la disciplinele op ionale.

\section{Rezultatele ob inute}

\subsection{Scopul op ionalelor, în viziunea părin ilor}

Opiniile părin ilor nu diferă mult de cele exprimate de către profesori în studiile opinionale recente, men ionate în acest material. Scopul pentru care sunt propuse aceste op ionale, în viziunea părin ilor, este de a adapta educa ia formală a elevului la interesele de moment sau de perspectivă ale acestuia. În general, aceste discipline op ionale ar trebui să dezbată teme mai complexe decât cele din trunchiul comun, să integreze informa ii, algoritmi, scheme de lucru etc. din mai multe discipline fundamentale şi să contribuie astfel la construirea cunoaşterii elevului, la dezvoltarea armonioasă a acestuia şi la conectarea teoriilor disciplinare cu via a de zi cu zi. De aceea, sunt necesare, aşa cum sus ine un părinte, ,,sondaje efectuate din timp în rândul părin ilor şi al copiilor pentru identificarea dorin ei acestora privind diversificarea domeniilor de învă are; identificarea lacunelor în programele şcolare, în materiile cuprinse în curriculumul şcolar, astfel încât să se acopere nevoile de aplicabilitate practică, de corelare interdisciplinară, de ieşire activă a copiilor din mediul de învă are teoretică, către cel practic; dezvoltarea unor discipline care să stimuleze originalitatea copiilor şi nevoia lor de a se remarca prin ini iativă şi implicare atât personală, cât şi la nivelul unor echipe de proiect" (opinia unui părinte).

Aceste discipline ar trebui elaborate astfel încât să dezvolte anumite deprinderi intelectuale şi motiva ia pentru învă are ale elevilor afla i la nivelul învă ământului gimnazial: ,,ar trebui ca materiile op ionale să exploateze capacitatea copiilor de a re ine lucruri noi şi interesante. Din acest motiv, aceste op ionale ar trebui alese astfel încât să îi atragă pe copii şi să îi facă să îşi dorească să afle cât mai mult" (opinia unui părinte). 
Referitor la scopul op ionalelor: mediile răspunsurilor sunt, în general, apropiate de mediana intervalului valoric, diferen ele existente ierarhizând totuşi opiniile părin ilor, în timp ce coeficien ii de varia ie (situa i între $30.67 \%$ şi 42.22\%) demonstrează o omogenitate destul de bună a răspunsurilor (a se vedea tabelul nr. 1).

Opinia cel mai des exprimată de părin ii responden i este că o disciplină op ională trebuie să răspundă unor interese exprimate de majoritatea elevilor (media valorică este 3.58, apropiată de alegerea ,în mare măsură”, diferen ele de opinie fiind măsurate printr-o abatere standard de 1.10); urmează, în această ierarhie, opiniile conform cărora un op ional ar trebui să interconecteze disciplinele obligatorii studiate sau elementele teoretice cu via a cotidiană, prin intermediul unor teme mai complexe, respectiv să contribuie la formarea armonioasă a personalită ii elevului (ambele variante având o medie de 3.40). Următoarele alegeri ale părin ilor au fost acelea care afirmau ca scopul pentru care este propus un op ional ar trebui să fie acela de a stimula motiva ia pentru studiu (3.38), respectiv de a demonstra valen e practice mai puternice decât disciplinele obligatorii (3.28), ambele variante fiind caracterizate prin alegerea ,în măsură medie".

Oarecum surprinzător, părin ii par să admită faptul că o disciplină op ională ar putea fi menită, uneori, să completeze norma didactică a unui profesor (cu o medie de 2.90, apropiată valoric de varianta ,în măsură medie", dar având un coeficient de varia ie de $42.22 \%$, ceea ce demonstrează că răspunsurile au fost mai diversificate, comparativ cu alte variante).

$\mathrm{Cu}$ toate că numărul părin ilor cu copii în clasa a VIII-a, din cadrul eşantionului, a fost mai redus (sub 25\% din totalul părin ilor participan i la studiu), media răspunsurilor care consideră că scopul op ionalelor este de a pregăti elevii pentru testările na ionale este foarte apropiată de mediana intervalului valoric, ceea ce reflectă ideea că disciplinele op ionale pot sprijini pregătirea pentru aceste examene na ionale, încă din clasa a V-a (în măsură medie). 
Tabelul nr. 1. Scopul disciplinelor op ionale din şcoală

\begin{tabular}{|l|c|c|c|c|c|c|c|c|}
\hline $\begin{array}{l}\text { Scopul pentru care } \\
\text { este propus } \\
\text { op ionalul trebuie } \\
\text { să fie: }\end{array}$ & $\begin{array}{c}\text { Deloc } \\
(1)\end{array}$ & $\begin{array}{c}\text { În mică } \\
\text { măsură } \\
(2)\end{array}$ & $\begin{array}{c}\text { În } \\
\text { măsură } \\
\text { medie } \\
(3)\end{array}$ & $\begin{array}{c}\text { În mare } \\
\text { măsură } \\
(4)\end{array}$ & $\begin{array}{c}\text { În foarte } \\
\text { mare } \\
\text { măsură } \\
(5)\end{array}$ & Media & $\begin{array}{c}\text { Abaterea } \\
\text { standard }\end{array}$ & $\begin{array}{c}\text { Coef. } \\
\text { de } \\
\text { varia ie }\end{array}$ \\
\hline $\begin{array}{l}\text { 1. de a răspunde } \\
\text { unor interese } \\
\text { exprimate de } \\
\text { majoritatea elevilor }\end{array}$ & $5.00 \%$ & $12.50 \%$ & $22.50 \%$ & $40.00 \%$ & $20.00 \%$ & 3.58 & 1.10 & $30.67 \%$ \\
\hline $\begin{array}{l}\text { 2. de a interconecta } \\
\text { disciplinele } \\
\text { obligatorii studiate } \\
\text { sau elementele } \\
\text { teoretice cu via a } \\
\text { cotidiană }\end{array}$ & $5.00 \%$ & $17.50 \%$ & $30.00 \%$ & $27.50 \%$ & $20.00 \%$ & 3.40 & 1.14 & $33.51 \%$ \\
\hline $\begin{array}{l}3 . \text { de a contribui la } \\
\text { formarea } \\
\text { armonioasă a } \\
\text { personalită ii } \\
\text { elevului }\end{array}$ & $5.00 \%$ & $15.00 \%$ & $35.00 \%$ & $25.00 \%$ & $20.00 \%$ & 3.40 & 1.12 & $32.85 \%$ \\
\hline $\begin{array}{l}4 . \text { de a stimula } \\
\text { motiva ia elevilor } \\
\text { pentru studiu }\end{array}$ & $7.50 \%$ & $15.00 \%$ & $27.50 \%$ & $32.50 \%$ & $17.50 \%$ & 3.38 & 1.16 & $34.33 \%$ \\
\hline $\begin{array}{l}5 . \text { de a avea valen e } \\
\text { practice mai } \\
\text { puternice decât } \\
\text { disciplinele } \\
\text { obligatorii }\end{array}$ & $7.50 \%$ & $22.50 \%$ & $22.50 \%$ & $30.00 \%$ & $17.50 \%$ & 3.28 & 1.21 & $36.88 \%$ \\
\hline $\begin{array}{l}\text { 6. pregătirea pentru } \\
\text { testările na ionale }\end{array}$ & $12.50 \%$ & $22.50 \%$ & $27.50 \%$ & $30.00 \%$ & $7.50 \%$ & 2.98 & 1.15 & $38.80 \%$ \\
\hline $\begin{array}{l}7 . \text { completarea unor } \\
\text { norme didactice }\end{array}$ & $13.75 \%$ & $27.50 \%$ & $25.00 \%$ & $22.50 \%$ & $11.25 \%$ & 2.90 & 1.22 & $42.22 \%$ \\
\hline
\end{tabular}

6. 2. Opiniile părin ilor despre oferta şcolii privind disciplinele op ionale

Părin ii sunt de părere că disciplinele op ionale sunt, în general, preluate de la un an la altul, în cadrul aceleiaşi şcoli sau sunt preluate din oferta na ională a op ionalelor deja aprobate (media răspunsurilor referitoare la reluarea anuală a op ionalelor a fost 3.73, iar cea privind preluarea lor din oferta centrală a fost 3.51, ambele fiind apropiate de varianta ,în mare măsură”, cu mici varia ii ale răspunsurilor). Multe discipline op ionale sunt preluate într-o şcoală de la un an la altul, pe baza unui feedback pozitiv de la promo iile anterioare; 
de asemenea, op ionalele preluate din oferta na ională sunt considerate a fi bune, deoarece au fost deja testate.

Tabelul nr. 2. Realizarea sau preluarea disciplinelor op ionale din şcoală

\begin{tabular}{|l|c|c|c|c|c|c|c|c|}
\hline $\begin{array}{l}\text { În general, } \\
\text { disciplinele } \\
\text { op ionale: }\end{array}$ & $\begin{array}{c}\text { Deloc } \\
(1)\end{array}$ & $\begin{array}{c}\text { În mică } \\
\text { măsură } \\
(2)\end{array}$ & $\begin{array}{c}\text { În măsură } \\
\text { medie } \\
(3)\end{array}$ & $\begin{array}{c}\text { În mare } \\
\text { măsură } \\
(4)\end{array}$ & $\begin{array}{c}\text { În foarte } \\
\text { mare } \\
\text { măsură } \\
(5)\end{array}$ & Media & $\begin{array}{c}\text { Abaterea } \\
\text { standard }\end{array}$ & $\begin{array}{c}\text { Coef. } \\
\text { de } \\
\text { varia ie }\end{array}$ \\
\hline $\begin{array}{l}\text { 1. sunt preluate } \\
\text { de la un an la } \\
\text { altul, mai ales } \\
\text { cele care au } \\
\text { avut succes }\end{array}$ & $2.50 \%$ & $10.00 \%$ & $25.00 \%$ & $37.50 \%$ & $25.00 \%$ & 3.73 & 1.03 & $27.59 \%$ \\
\hline $\begin{array}{l}\text { 2. sunt } \\
\text { preluate, in } \\
\text { mare parte, din } \\
\text { oferta } \\
\text { na ională }\end{array}$ & $2.50 \%$ & $12.50 \%$ & $40.00 \%$ & $25.00 \%$ & $20.00 \%$ & 3.51 & 1.00 & $28.61 \%$ \\
\hline $\begin{array}{l}3 . \text { sunt } \\
\text { realizate de } \\
\text { unul sau mai } \\
\text { mul i profesori } \\
\text { care excelează } \\
\text { în unele } \\
\text { domenii }\end{array}$ & $10.00 \%$ & $12.50 \%$ & $30.00 \%$ & $42.50 \%$ & $5.00 \%$ & 3.20 & 1.06 & $33.03 \%$ \\
\hline $\begin{array}{l}4 . \text { sunt } \\
\text { elaborate } \\
\text { pentru a } \\
\text { completa } \\
\text { norme } \\
\text { didactice }\end{array}$ & $12.50 \%$ & $20.00 \%$ & $32.50 \%$ & $30.00 \%$ & $5.00 \%$ & 2.95 & 1.10 & $37.21 \%$ \\
\hline
\end{tabular}

Coeficien ii de varia ie ob inu i pentru acest item au valori cuprinse între $27.59 \%$ şi $37.21 \%$, ceea ce indică un grad acceptabil de omogenitate a seriilor numerice ob inute, respectiv faptul că mediile calculate sunt reprezentative pentru tendin ele centrale ale răspunsurilor.

6.3. Opiniile părin ilor despre modalită ile de selec ie a op ionalelor în şcoală

Selec ia op ionalelor se face în fiecare an şcolar prin vot, din oferta disponibilă care este prezentată în liste de oferte pentru fiecare clasă (media de 4.55 dintr-un maximum de 5 arată că părin ii au această opinie ,,în foarte mare 
măsură”, varia ia răspunsurilor fiind foarte mică). Câteodată structurile şcolare implicate şi ISJ-urile sunt cele care hotărăsc listele de op ionale finale ale unei şcoli (media de 3.18).

Părin ii sunt de părere că unele op ionale ar trebui organizate cu elevii care au interese de studiu comune şi nu cu toată clasa, aşa cum sunt organizate acum (media 3.13).

O parte dintre părin i consideră că ar trebui organizate în grupuri mai mici de elevi, pentru a reflecta cu adevărat interesele elevilor (media 3.13). Un părinte recomandă chiar renun area la op ionale şi ,,înfiin area la nivelul şcolii a diferitelor cercuri (geografie, istorie, fizică etc.) în care copiii pasiona i de astfel de materii se pot regăsi şi excela".

Dirigintele clasei este un factor care poate influen a alegerile părin ilor, dar în mai mică măsură (media 2,63). Uneori părin ii află despre op ionale şi din alte surse, de pe site-ul şcolii sau din diverse materiale realizate cu scopul promovării op ionalelor (media 2.10 arată că solu ia aceasta este mai rar întâlnită, oferta de op ionale este rareori anun ată prin alte mijloace decât prin discu iile din şedin ele cu părin ii).

O altă opinie generală rezultată este aceea că procedurile de alegere a disciplinelor op ionale ar trebui simplificate, astfel încât să existe mai mult timp pentru propunerea şi alegerea acestora. Părin ii consideră că structurile de conducere ale şcolii şi inspectoratele şcolare jude ene / al Municipiului Bucureşti hotărăsc op ionalele prin procesul de aprobare numai în măsură moderată, în timp ce ei, în calitate de părin i, sunt direct responsabili de configura ia actuală a op ionalelor dintr-o şcoală, fapt pentru care ar trebui să se implice mai mult în acest proces. Din răspunsurile părin ilor, alegerea op ionalelor are o mică legătură cu notele pe care le vor primi elevii (media 1.68), poate pentru că, în general, notele ob inute la aceste discipline sunt foarte bune (de obicei, se acordă nota maximă). 
Tabelul nr. 3. Modalitatea de selec ie a disciplinelor op ionale

\begin{tabular}{|l|c|c|c|c|c|c|c|c|}
\hline $\begin{array}{l}\text { Selec ia } \\
\text { disciplinelor } \\
\text { op ionale se face: }\end{array}$ & $\begin{array}{c}\text { Deloc } \\
(1)\end{array}$ & $\begin{array}{c}\text { În mică } \\
\text { măsură } \\
(2)\end{array}$ & $\begin{array}{c}\text { În măsură } \\
\text { medie } \\
(3)\end{array}$ & $\begin{array}{c}\text { În mare } \\
\text { măsură } \\
(4)\end{array}$ & $\begin{array}{c}\text { În foarte } \\
\text { mare } \\
\text { măsură } \\
(5)\end{array}$ & Media & $\begin{array}{c}\text { Abatere } \\
\text { standard }\end{array}$ & $\begin{array}{c}\text { Coef. de } \\
\text { varia ie }\end{array}$ \\
\hline $\begin{array}{l}\text { 1. dintr-o listă de } \\
\text { discipline propuse }\end{array}$ & $0.00 \%$ & $2.50 \%$ & $2.50 \%$ & $32.50 \%$ & $62.50 \%$ & 4.55 & 0.67 & $14.75 \%$ \\
\hline $\begin{array}{l}\text { 2. conducerea şcolii } \\
\text { si inspectoratele } \\
\text { școlare sunt cele } \\
\text { care hotărăsc }\end{array}$ & $12.50 \%$ & $20.00 \%$ & $22.50 \%$ & $27.50 \%$ & $17.50 \%$ & 3.18 & 1.29 & $40.52 \%$ \\
\hline $\begin{array}{l}3 . \text { ar trebui } \\
\text { organizate pe } \\
\text { grupuri mai mici de } \\
\text { elevi, care să nu fie } \\
\text { neapărat de la o } \\
\text { clasă }\end{array}$ & $17.50 \%$ & $17.50 \%$ & $22.50 \%$ & $20.00 \%$ & $22.50 \%$ & 3.13 & 1.40 & $44.93 \%$ \\
\hline $\begin{array}{l}4 . \text { dirigintele / } \\
\text { profesorul care va } \\
\text { preda disciplina este } \\
\text { cel care convinge }\end{array}$ & $20.00 \%$ & $27.50 \%$ & $27.50 \%$ & $20.00 \%$ & $5.00 \%$ & 2.63 & 1.16 & $44.14 \%$ \\
\hline $\begin{array}{l}5 . \text { de pe site-ul } \\
\text { şcolii, broşuri sau } \\
\text { alte materiale care } \\
\text { promovează un } \\
\text { op ional }\end{array}$ & $30.00 \%$ & $45.00 \%$ & $12.50 \%$ & $10.00 \%$ & $2.50 \%$ & 2.10 & 1.02 & $48.71 \%$ \\
\hline $\begin{array}{l}6 . \text { având în vedere } \\
\text { notele pe care le vor } \\
\text { primi elevii }\end{array}$ & $62.50 \%$ & $20.00 \%$ & $7.50 \%$ & $7.50 \%$ & $2.50 \%$ & 1.68 & 1.06 & $63.36 \%$ \\
\hline
\end{tabular}

Răspunsurile libere arată că mai pu in de $40 \%$ dintre responden i au propus un op ional şi, exceptând câteva persoane, propunerile lor au rămas fără ecou. Este nevoie, după părerea acestor părin i, de o comunicare mai bună între şcoală şi familie, dacă se doreşte cu adevărat ca aceste op ionale să fie în interesul elevului.

6.4. Avantajele conferite de disciplinele op ionale, în viziunea părin ilor

Opiniile părin ilor participan i la studiu au fost în mare măsură convergente în privin a avantajelor oferite elevilor de către op ionale. Conform răspunsurilor ob inute, utilitatea disciplinelor op ionale ar consta, în primul rând, în ob inerea unor note mai bune la disciplinele înrudite, respectiv în creşterea încrederii în sine şi a motiva iei de a învă a (ambele cotate, ,în mare măsură”, cu o medie de 3.55, prima variantă având în schimb un coeficient de varia ie uşor mai redus). 
Alte avantaje constau în construirea unor rela ii mai bune în clasă şi o comunicare mai bună între clasa de elevi şi profesor (media 3.43, respectiv media 3.40). Părin ii recunosc, de asemenea, posibilitatea îmbunătă irii rezultatelor la testările na ionale datorită competen elor specifice formate la disciplinele op ionale (media 3.23).

Tabelul nr. 4. Utilitatea disciplinelor op ionale

\begin{tabular}{|l|c|c|c|c|c|c|c|c|}
\hline $\begin{array}{l}\text { Op ionalele } \\
\text { s-au dovedit } \\
\text { utile pentru: }\end{array}$ & $\begin{array}{c}\text { Deloc } \\
(1)\end{array}$ & $\begin{array}{c}\text { În mică } \\
\text { măsură } \\
(2)\end{array}$ & $\begin{array}{c}\text { În } \\
\text { măsură } \\
\text { medie } \\
(3)\end{array}$ & $\begin{array}{c}\text { În mare } \\
\text { măsură } \\
(4)\end{array}$ & $\begin{array}{c}\text { In foarte } \\
\text { mare } \\
\text { măsură } \\
(5)\end{array}$ & Media & $\begin{array}{c}\text { Abatere } \\
\text { standard }\end{array}$ & $\begin{array}{c}\text { Coef. de } \\
\text { variabilitate }\end{array}$ \\
\hline $\begin{array}{l}\text { 1. creşterea } \\
\text { increderii in } \\
\text { sine şi a } \\
\text { motiva iei de a } \\
\text { învă a }\end{array}$ & $10.00 \%$ & $15.00 \%$ & $12.50 \%$ & $35.00 \%$ & $27.50 \%$ & 3.55 & 1.31 & $36.82 \%$ \\
\hline $\begin{array}{l}\text { 2. ob inerea } \\
\text { unor note mai } \\
\text { bune la } \\
\text { disciplinele } \\
\text { înrudite }\end{array}$ & $5.00 \%$ & $15.00 \%$ & $22.50 \%$ & $35.00 \%$ & $22.50 \%$ & 3.55 & 1.14 & $32.19 \%$ \\
\hline $\begin{array}{l}3 . \text { îmbunătă irea } \\
\text { interac iunii } \\
\text { elevului cu } \\
\text { colegii din } \\
\text { clasă }\end{array}$ & $12.50 \%$ & $17.50 \%$ & $17.50 \%$ & $20.00 \%$ & $32.50 \%$ & 3.43 & 1.42 & $41.36 \%$ \\
\hline $\begin{array}{l}4 . \text { îmbunătă irea } \\
\text { comunicării cu } \\
\text { profesorul care } \\
\text { predă disciplina }\end{array}$ & $10.00 \%$ & $15.00 \%$ & $25.00 \%$ & $25.00 \%$ & $25.00 \%$ & 3.40 & 1.28 & $37.78 \%$ \\
\hline $\begin{array}{l}5 . \text { îmbunătă irea } \\
\text { rezultatului la } \\
\text { testarea } \\
\text { na ională }\end{array}$ & $10.00 \%$ & $15.00 \%$ & $22.50 \%$ & $45.00 \%$ & $7.50 \%$ & 3.25 & 1.12 & $34.34 \%$ \\
\hline $\begin{array}{l}\text { 6. mărirea } \\
\text { mediei generale }\end{array}$ & $25.00 \%$ & $17.50 \%$ & $22.50 \%$ & $30.00 \%$ & $5.00 \%$ & 2.73 & 1.27 & $46.56 \%$ \\
\hline
\end{tabular}

Din analiza răspunsurilor părin ilor, se constată că există o corela ie directă, moderată, între selectarea op ionalelor pentru notele pe care le vor primi elevii şi utilitatea op ionalelor pentru mărirea mediei generale a elevilor. Coeficientul de corela ie Pearson, care măsoară gradul de legătură între variabile, are o valoare de 0.46 în cazul celor două variabile, ecua ia de regresie care exprimă matematic legătura dintre aceste variabile fiind y = $0.382 x+0.635$. 
Acelaşi tip de legătură pozitivă se stabileşte şi între scopul explicit al op ionalelor pentru exersare la testarea na ională şi utilitatea percepută în acest sens de către părin i, coeficientul de corela ie Pearson fiind de 0.57 (deci o corela ie medie spre înaltă), dreapta de regresie fiind în acest caz $\mathrm{y}=0.591 \mathrm{x}+1.055$.

\section{Concluzii}

Societatea actuală pune în fa a sistemelor educa ionale o serie de provocări, cum ar fi construirea societă ii cunoaşterii în condi iile unei globalizări tot mai accentuate, educa ia pentru o dezvoltare durabilă, utilizarea extinsă a tehnologiei informa iei şi comunica iilor etc. Acestea îşi pun amprenta pe ofertele educa ionale complementare trunchiului comun, astfel încât apar teme/domenii de studiu corelate cu noile educa ii precum: educa ia europeană, matematica şi ştiin ele în societatea cunoaşterii, educa ie ecologică etc. $\mathrm{O}$ parte dintre aceste teme se regăsesc în oferta centrală de discipline op ionale, aşa că unele şcoli le preiau direct de acolo. Deşi op ionalele sunt un îndemn pentru profesori la creativitate şi curaj de a veni cu noi oferte curriculare, preluarea unor discipline care s-au bucurat de succes limitează riscurile, de aceea o parte a ofertei ,personalizate” a şcolii este de fapt cvasi-comună, putând fi regăsită şi în multe alte unită i şcolare.

La nivel european, se acordă astăzi o mare aten ie validării experien elor nonformale de învă are şi integrării acestora în educa ia formală. În acest sens, o modalitate ar fi de a crea conexiuni între activită ile desfăşurate în programul Şcoala altfel ,Să ştim mai multe, să fim mai buni!” şi disciplinele obligatorii, prin intermediul disciplinelor op ionale. Părin ii consideră că disciplinele op ionalele sunt un bun prilej de a aprofunda ceea ce copiii înva ă în şcoală, în familie, în comunitate sau prin mass media.

Diversitatea tematică a disciplinelor op ionale nu este atât de mare pe cât s-ar dori, fiind influen ată de mărimea şcolii, de numărul şi de calitatea parteneriatelor realizate de unitatea şcolară (în general, toată clasa participă la un op ional, chiar dacă sunt elevi care şi-au exprimat clar dezinteresul pentru disciplina respectivă). Ar trebui, în opinia părin ilor, ca aceste op ionale să fie negociate din timp (să se utilizeze chestionare de opinie şi să se dezbată 
în şedin e), să fie mai practice, să aibă aplicabilitate în cotidian, să fie captivante, relaxante şi interactive: ,,atunci când au valen e practice mai puternice decât disciplinele obligatorii, contribuie la dezvoltarea armonioasă a personalită ii elevului şi cresc încrederea în sine şi motiva ia de a învă a" (opinia unui părinte). Este necesară o anumită continuitate între clase sau formarea unor legături între aceste discipline. De aceea, părin ii, elevii şi şcoala ar trebui să găsească răgaz, la începutul unui ciclu de învă ământ, să facă o propunere asupra disciplinelor op ionale pe care elevii le pot studia în cei 4 ani (este deci nevoie de o proiectare pe un termen mai lung, respectiv pe un întreg ciclu de învă ământ).

Oferta curriculară propusă de şcoală poate fi privită şi ca o modalitate de a eviden ia competen ele unor elevi care au activită i şi interese de studiu mai deosebite. Deşi în toate documentele oficiale profesorii sunt invita i fie să conecteze temele disciplinei cu teme specifice altor discipline, pentru a construi o perspectivă pluridisciplinară/interdisciplinară, fie cu experien ele de via ă ale elevului, în realitate unii profesori încă predau într-o manieră teoretică sau deductivă, chiar şi în cazul disciplinelor op ionale (de la elementele teoretice abstracte, către practic sau particular şi nu depăşesc sfera disciplinară).

Există şi o serie de nemul umiri exprimate de părin i şi ne referim la faptul că op iunea personală nu contează, atât timp cât, ,disponibilitatea şcolii este limitată", calitatea op ionalelor este afectată de formarea uneori deficitară a profesorilor (atât cea ini ială, cât şi cea continuă), iar variantele de alegere a unor op ionale sunt pu ine. Chiar şi insistarea pe disciplinele care se evaluează la sfârşitul clasei a VIII-a ignoră ,,nevoia de dezvoltare a culturii generale a copiilor" sau diferen ele dintre elevi. Deoarece comunicarea părinte elev - diriginte se desfăşoară în mai multe etape, uneori op ionalele ,sunt alese de părin i, fără a fi consulta i şi copiii, motiv pentru care devin un calvar pentru aceştia". În încercarea, destul de dificilă, de a armoniza ceea ce doreşte elevul cu dorin ele părintelui (care are deja anumite preten ii formate pentru cariera copilului său) şi cu motiva iile profesorului (care, în ipostaza sa de evaluator, poate să identifice tendin e comportamentale, talente, înclina ii ale elevului etc), de obicei primele sacrificate sunt motiva iile şi interesele de studiu ale elevilor. Un părinte sesiza că ,nevoile şi cerin ele elevilor sunt tratate superficial de către toate păr ile implicate". 


\section{Referin e}

- Balica, M., \& Fartuşnic, C. (Coord.). 2018. Opinii privind importan a autonomiei şcolii în plan curricular. În Raport de consultare publică privind propunerile de plan-cadru pentru liceu, filiera teoretică. Bucureşti: Institutul de Ştiin e ale Educa iei, (pp. 25-28). Disponibil la: http://www.ise.ro/wp-content/uploads/2018/ 04/Raport_consultare_plan-cadru_liceu_final_final.pdf (accesat la 01.08.2018).

- Brickell, H. (1974). State organization for educational change: a case study and a proposal. New York: Teachers College Press.

- Catană, L. (2010). Metodologia implementării competen elor cheie în curriculumul şcolar. Revista de Pedagogie, 58(3), 249-252.

- Catană, L., \& Mândru , O. (2011). Abordarea integrată a curriculumului şcolar. Revista de Pedagogie, 59(4), 93-100.

- Catană, L., Mândru, O., \& Dan, S. (2012). Dimensiuni interdisciplinare şi supradisciplinare ale instruirii pe competen e. În: A. Ardelean. \& O. Mândru (Coord.), Didactica formării competen elor (pp. 55-69). Arad: „Vasile Goldiş” University Press.

- Cocişiu, T. (2012). Tehnica pedagogică de cercetare şi crea ie. Baia Mare: Editura Surorilor Lauretane.

- Department for Education (2011). The Framework for the National Curriculum. A report by the Expert Panel for the National Curriculum review. London: Department for Education. Disponibil la: https://www.gov.uk/government/up loads/system/uploads/attachment_data/file/175439/NCR-Expert_Panel_ Report.pdf (accesat la 01.08.2018).

- Gardner, H.E. (2005). Mintea disciplinată. Bucureşti: Editura Sigma.

- Institutul de Ştiin e ale Educa iei. 2016. Repere pentru proiectarea şi actualizarea curriculumului na ional. Document de politici educa ionale. Bucureşti. Versiune de lucru Mai 2016 disponibilă la: http://www.ise.ro/wp-content/uploads/ 2015/07/Document-politici-curriculum_draft_mai_2016.pdf (accesată la 24.08.2018).

- Mândru, O. (Coord.) (2010). Metodologia proiectării şi aplicării curriculumului la decizia şcolii. Bucureşti: Institutul de Ştiin e ale Educa iei.

- Miles, M. (1964). Innovation in education. New York: Teachers College Press.

- Ministerul Educa iei Na ionale. 2014. Metodologia privind elaborarea şi aprobarea curriculumului şcolar - planuri-cadru de învă ământ şi programe scolare (anexă la a Ordinul ministrului educa iei na ionale nr. 3593 / 18.06.2014). Disponibil la: http://www.ise.ro/wp-content/uploads/2014/08/ Metodologie-Curriculum.pdf (accesat la 24.08.2018).

- Potolea, D. (Coord.) (2012). Coordonate ale unui nou cadru de referin ă al curriculumului na ional. Bucureşti: Editura Didactică şi Pedagogică. 
- $\quad$ ăranu, A.M. (2007). DPPD, Sinteze. Bucureşti: Editura Funda iei România de Mâine.

The online version of this article can be found at: http://revped.ise.ro/category/2018-en/

\section{(cc) BY-NC-sA}

This work is licensed under the Creative Commons Attribution-NonCommercial-ShareAlike 4.0 International License.

To view a copy of this license, visithttp://creativecommons.org/licenses/by-ncsa/4.0/ or send a letter to Creative Commons, $P O$ Box 1866, Mountain View, CA 94042, USA.
Versiunea online a acestui articol poate fi găsită la:http://revped.ise.ro/category/2018-ro/

\section{(cc) EY-Ne-sA}

Această lucrare este licen iată sub Creative Commons Attribution-NonCommercial-ShareAlike 4.0 International License.

Pentru a vedea o copie a acestei licen e, vizita $i$ http://creativecommons.org/licenses/by-nc-sa/4.0/ sau trimite i o scrisoare către Creative Commons, PO Box 1866, Mountain View, CA 94042, SUA. 